\title{
The Impact of Public Expenditure Components on Economic Growth in Ethiopia; Vector Autoregressive Approach
}

\author{
Endaylalu Solomon \\ Department of Economics, Jinka University, Jinka, Ethiopia
}

Email address:

getendex@gmail.com

\section{To cite this article:}

Endaylalu Solomon. The Impact of Public Expenditure Components on Economic Growth in Ethiopia; Vector Autoregressive Approach. International Journal of Business and Economics Research. Vol. 8, No. 4, 2019, pp. 211-219. doi: 10.11648/j.ijber.20190804.16

Received: June 12, 2019; Accepted: July 10, 2019; Published: July 26, 2019

\begin{abstract}
The study analyzes the impact of public expenditure components on economic growth in the Ethiopian economy using annual time series data for the period 1982-2016. The study uses public expenditure variables from economic infrastructures (agriculture, road and energy), social infrastructure (education) and recurrent and capital expenditure components. With the help of co-integration and vector error correction analysis, the impact of various areas of public expenditures was assessed in the long-run as well as in the short-run. The study found that public expenditure components at all have a significant positive effect on economic growth in the long-run but they have insignificant impact in the short-run except education and road. Expenditure on education and road has both short-run and long run effects on economic growth. The impact of educational expenditure on economic growth is highly significant and positive which have powerful role in promoting the country's economic growth compared to other variables. In the short run the impact of education on economic growth is negative and significant whereas that of road expenditure is significant and positive. Based on the results of the cointegrated and vector error correction model, this study found that, it is better and advisable to have an excessive expenditure on education and road construction than other areas of public expenditure, so as to accelerate economic growth in Ethiopia.
\end{abstract}

Keywords: Economic Growth, Economic Infrastructure, Public Expenditure, Social Infrastructure

\section{Introduction}

The crowding out effect of public investment has raised some other issues in contrary to this crowding out effect. [11] A stylized fact for many industrialized economies is the marked decline in the ratio of public investment to gross domestic product that has occurred over the last three decades. However, this decline have not bring improvements in private investment and it has raised concerns that public capital stocks have fallen to sub-optimal levels, possibly reducing private sector productivity and imposing a constraint on economic growth instead of tackling crowding out effect.

Roads have been built and expanded; however, it is not always a success story. [16] There are critics that challenge the successes of these projects. Some federal road projects are constructed in the remote areas where the traffic volume is far below the minimum average. One can easily understand that these projects could not generate sufficient additional revenues for the government, nor could they cover their running and maintenance costs. On the other hand, the government has no financial capacity and is not allocating sufficient funds for maintenance and operation. The government might have political or social objectives to invest in those areas, but unless these investment projects have adequate economic return, their positive effects could not be sustainable.

On the other hand, the development of large- and mediumscale hydropower projects has received priority, and the government is investing a large amount of money on these projects. The government believes that economic progress in Ethiopia depends principally on the development of large hydropower projects though smaller-scale water projects are also suited in meeting the immediate needs of the poor nation. In the last couple of years, Ethiopia has developed large and medium-sized dams. For instance, Gibe I, II and III 
projects have been implemented and have started operation. Similarly, the Grand Ethiopian Renaissance Dam is now being developed and it is expected to cost US $\$ 4.8$ billion [16]. Hydropower projects are expensive and need huge investments. The size of the investment and the environmental and social impacts of the investment underline the need to choose projects wisely. Generally, the appraisal of energy investments requires a long-time perspective. Misjudgment can result in financial as well as economic disaster [3].

\subsection{Statement of the Problem}

How big is the contribution of infrastructure to aggregate economic performance - e.g., the level and/or growth rate of GDP? The answer is critical for many policy decisions - for example, to gauge the growth effects of fiscal interventions in the form of public investment changes, or to assess if public infrastructure investments can be self-financing. The empirical literature aimed to offer such quantitative assessments took off with the seminal work of Aschauer [5] on the effects of public infrastructure capital on U.S. total factor productivity (TFP). Using time-series data, he found an extremely (and, for most observers, implausibly) large effect [4].

The research seeking to find the government size that maximizes the rate of economic growth identifies aspects of government that tend to slow the rate of economic growth. Excess transfer payment programs or safety net programs are most commonly identified. Weaker education systems and corrupt government are also identified. Of course, a nation need not seek to maximize its rate of economic growth, and the evidence suggests nations have other goals. There is much evidence supporting Wagner's Law, which indicates economic growth will translate into larger government size.

Currently, it is important to study that examining the composition of government spending affects economic growth in Ethiopia. Even if there is marvelous growth in the literature on public expenditure and economic growth, there are several gaps. There is no universal agreement on which composition of the expenditure has direct effect on economic growth. Related to this concept Abdu [1] tries to analyze the compositions of public expenditure to the growth of the Ethiopian economy. This will provide important information for the usages of limited public financial resources.

This study is interested on the impact of public expenditure components on economic growth. Even though there are many researchers, who have studies on this area, most of them were interested to use cross sectional data for different countries from different periods, $[6,13,14]$. Though these studies have their merits they severely suffer from the heterogeneity of the underlying data set, different estimation techniques, different time periods and different variable measurement techniques can yield different results $[8,13]$.

Using this paper, the researcher tries to identify various areas of public expenditure on economic growth of Ethiopia. In this study, public expenditure in infrastructures with detailed observation to economic infrastructures like road and energy (including mining), social infrastructural expenditures like expenditure in education and government recurrent and capital expenditures have been considered using time series data for Ethiopia.

In addition to the type of data used in the study, this research importantly addresses methodological gap using the Vector Autoregressive (VAR) model unlike the previous studies [1], which was based on simple OLS method. This study also used most recent data to explain the most recent economic phenomenons.

\subsection{Research Questions}

i. Which components of public expenditure have significant contribution to economic growth in Ethiopia in between 1982 and 2016?

ii. What is the relationship between economic growth and public expenditure on economic infrastructures in Ethiopia in the period between 1982 and 2016?

iii. What is the impact of public expenditure in general on economic growth in Ethiopia in between 1982 and $2016 ?$

\subsection{Objective of the Study}

\subsubsection{General Objective}

The general objective of this study was to identify the impact of public expenditure components on Economic growth in Ethiopia. Besides this general objective, the study has specific objectives.

\subsubsection{Specific Objectives}

i. To identify the most important areas of public expenditure components that affect economic growth in Ethiopia.

ii. Identifying the relationship between economic growth and public investment on economic infrastructures.

iii. To analyse the overall effect of infrastructural expenditures on economic growth in Ethiopia.

\section{Methodology of the Study}

\subsection{Data Types and Sources}

All the data that the researcher has used in this research were secondary. Since the analysis is time series, these data are expected to be time series which covers a sample of 35 years observations in between 1982 and 2016. Potential sources for these data are included both government and nongovernment organizations. Data source areas like Ministry of Finance and Economic Development (MoFED), World Development Indicator (WDI), Ethiopian Economic Association (EEA), Central Statistical Authority (CSA), and Ethiopian Investment Commission (EIC) will be used as a source of data.

\subsection{Data Analysis Method}

In general two kinds of data analysis tools will be employed in this research to analyze the data obtained from 
different sources. Explanatory data analysis tools like tables, graphs and charts are going to be used to explain the relationships and interactions of different variables in the sense for descriptive analysis. Econometric analysis will be the second tool used to analyze data. To investigate the shortrun and long-run relationship between public expenditure variables and economic growth, Vector Autoregressive (VAR) model will be importantly used, which can be explained as follows;

\subsubsection{Vector Autoregressive Model}

The vector autoregressive (VAR) model is one of the most successful, flexible, and easy to use models for the analysis of multivariate time series. It is a natural extension of the univariate autoregressive model to dynamic multivariate time series. The VAR model has proven to be especially useful for describing the dynamic behaviour of economic and financial time series and for forecasting. It often provides superior forecasts to those from univariate time series models and elaborate theory-based simultaneous equations models.
Forecasts from VAR models are quite flexible because they can be made conditional on the potential future paths of specified variables in the model [12].

\subsubsection{Model Specification}

Based on the objective of the study and description of general VAR model above, the specific model used for the analysis of data in this study can be defined as;

$$
\mathrm{RGDP}=\mathrm{f}(\mathrm{AGR}, \mathrm{EDUC}, \mathrm{ROAD}, \mathrm{ENER}, \mathrm{CAP}, \mathrm{RECU})
$$

From equation (1) above we can observe that real GDP expressed as a function of government expenditure on social infrastructure, i.e., education (EDUC), economic infrastructures, i.e., agriculture (AGR), road (ROAD) and energy (ENER), and its capital (CAP) and recurrent (RECU) expenditures.

To make the relationship between economic growth and public expenditure more simple and clear, it is important to re-express equation (1) in to a multiple linear regression model as;

$$
\mathrm{RGDP}=\beta_{0}+\beta_{1} \mathrm{AGR}+\beta_{2} \mathrm{EDUC}+\beta_{3} \mathrm{ROAD}+\beta_{4} \mathrm{ENER}+\beta_{5} \mathrm{CAP}+\beta_{6} \mathrm{RECU}+\epsilon
$$

Where, $\boldsymbol{\epsilon}$ is the stochastic/error term

Equation (2) above is a multiple linear regression model which is not really satisfying at label, since it may be faced by heteroskedasticity problem of the error term.

Log transformation makes the relationship among

$$
\text { LNRGDP }=\beta_{0}+\beta_{1} \text { LNAGR }+\beta_{2} \text { LNEDUC }+\beta_{3} \text { LNROAD }+\beta_{4} \text { LNENER }+\beta_{5} \text { LNCAP }+\beta_{6} \text { LNRE }+\epsilon
$$

Now, equation (3) becomes simpler for interpretation as well as better in describing the linear relationship between variables.

\subsubsection{Definition and Measurement of Variables}

Excluding the error term, the research has seven variables, one dependent and seven independent variables. Real GDP is defined as the amount of physical goods and service produced in a given country for a specific fiscal year.

Expenditure in each of the given independent variable can be defined as the total amount of government expenditure in each sector measured in terms of monetary values. For example expenditure on education refers to the total expenditure by the government on educational sector like for provision of educational materials and construction of schools.

Likewise, provision of agricultural inputs like fertilizer, pesticides, and herbicides and other chemicals, and different agricultural extension programs are involved with the hand of the government and it is included under the variable called expenditure on agriculture. Expenditure on road construction includes the total investment cost of the government involved in road transport sector and expenditure on energy includes the construction of dams for hydroelectric power generation and cost of utility supplies of the government related with power and expenditures on mining.

Recurrent expenditure represents expenses made by the government which are recurrent in nature, i.e., they are repeated. Normally, it is an expense on consumables that facilitate productive activities, for example, salaries of civil servants, purchase of raw materials, fuels and other factors of production. Capital expenditure represents expenses made by the government for the implementation and expansion of development projects. These are in the nature of acquisitions of fixed assets like buildings, machinery and equipment.

\section{Result and Discussion}

\begin{tabular}{|c|c|c|c|c|c|}
\hline Variables & Observation & Mean & Std. dev. & Min & Max \\
\hline RGDP & 35 & $2.85 \mathrm{e}+11$ & $1.95 \mathrm{e}+11$ & $1.20 \mathrm{e}+11$ & $8.10 \mathrm{e}+11$ \\
\hline AGR & 35 & 4247.33 & 6214.32 & 240.9 & 23770.28 \\
\hline EDUC & 35 & 9029.769 & 14583.88 & 282 & 51467.66 \\
\hline ROAD & 35 & 7514.705 & 13394.95 & 61.161 & 46119.21 \\
\hline
\end{tabular}

\subsection{Descriptive Analysis}

Table 1. Statistical summary of descriptive analysis. 


\begin{tabular}{llllll}
\hline Variables & Observation & Mean & Std. dev. & Min & Max \\
\hline ENER & 35 & 581.3853 & 424.809 & 106.2 & 1328.918 \\
RECU & 35 & 14336.37 & 23553.85 & 491.482 & 85667.57 \\
CAP & 35 & 10868.17 & 14598.26 & 347.3 & 57912.72 \\
\hline
\end{tabular}

Source; compiled from STATA results.

Based on the time series data to selected areas of public expenditure for the last 35 years, the descriptive analysis can be illustrated in the following three categories. This can be expenditure on education, expenditure on economic infrastructural areas and recurrent and capital expenditure components.

\subsubsection{Trends of Economic Growth and Expenditure on Education}

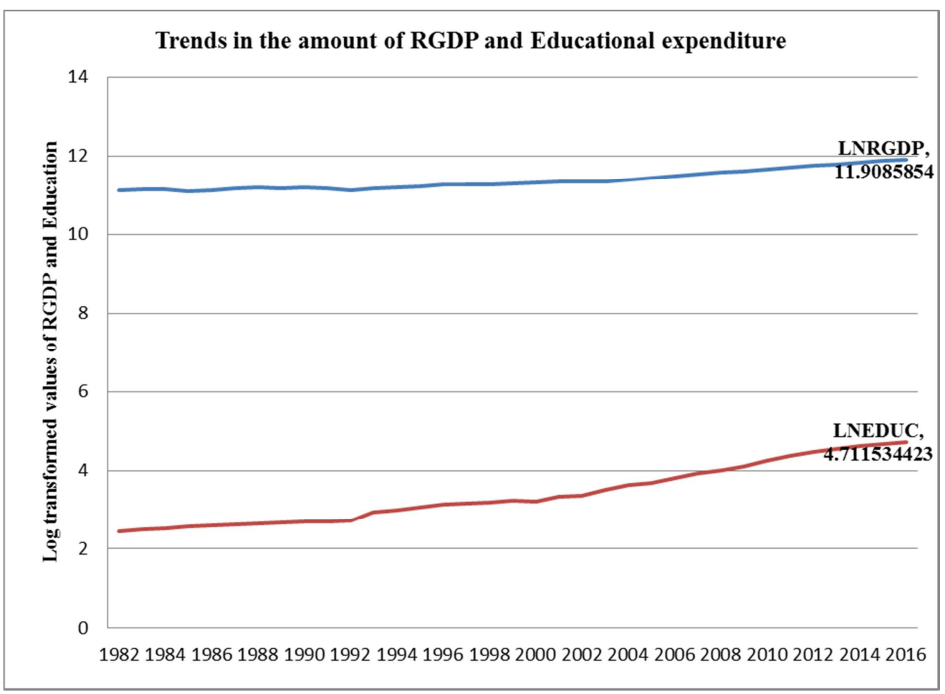

Source: compiled from WDI and EEA data sets.

Figure 1. Trends of Economic growth and Expenditure on Education.

A linear line LNRGDP in the above figure illustrates the existence of continuous increments in real GDP except the structural break point in 1984/85 and 1991/92. In 1984/85 the country was in a great famine which was caused from huge military expenditure of the military rule and decline in agricultural productivity due to drought. Similarly 1991/92 was a period of transition for the country from military rule to the current regime and the country was ruled under the transitional government. Because of these reasons, real GDP growth has experienced a negative growth rate in these two historical moments.

\subsubsection{Trends of Economic Growth and Expenditure on Economic Infrastructures}

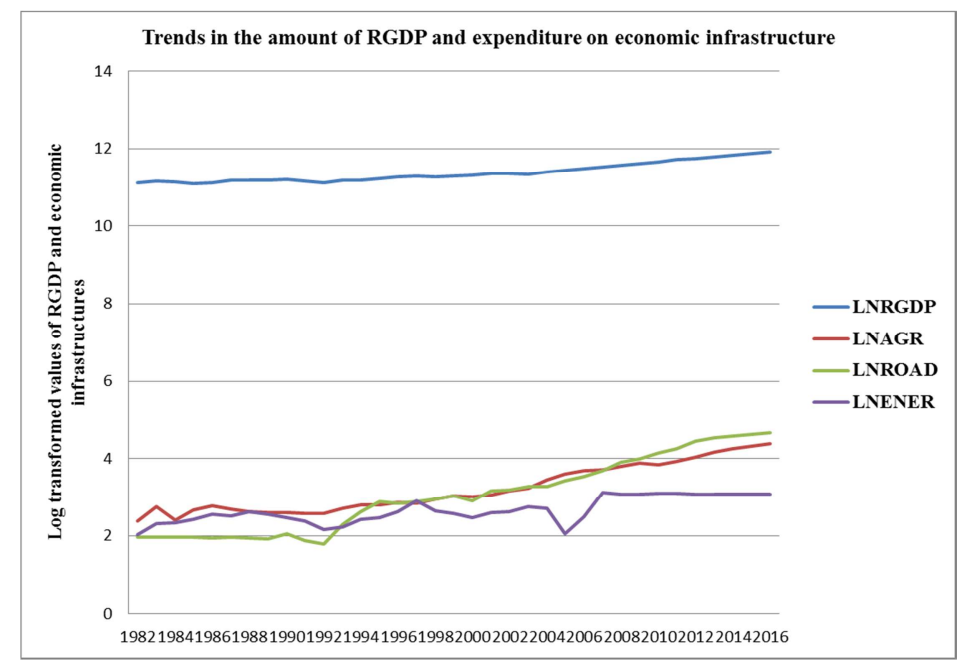

Source: compiled from WDI and EEA data sets.

Figure 2. Trends of Economic growth and Expenditure on Economic Infrastructures. 
From the above figure 2, we can summarize that government expenditure on agriculture and road was more or less linear and increasing over time for the last three and half decades. Whereas, expenditure on energy sub sector, including mining, was fluctuate until 2007 and more or less constant beyond 2007. During 2005, the time when the country was in a controversial national election and there were lots of economic destruction as a result of election campaign, public expenditure was switched from infrastructural areas to balloting funds. This causes to have a fluctuated graphical pattern as stated above for the trend of infrastructural expenditures as a whole but it was more sever for energy sub-sector.

\subsubsection{Trends of Economic Growth and Recurrent and Capital Expenditures}

Recurrent and capital expenditures in this case measure the total recurrent and capital expenditures other than these expenditures on agriculture, education, road and energy. Recurrent expenditure measures all expenses for consumable activities which are repeatedly occurring liquid transactions, while capital expenditure conveys those investment expenses by the government on different activities. Over the past 35 years both recurrent and capital expenditure have risen with many structural fluctuations.

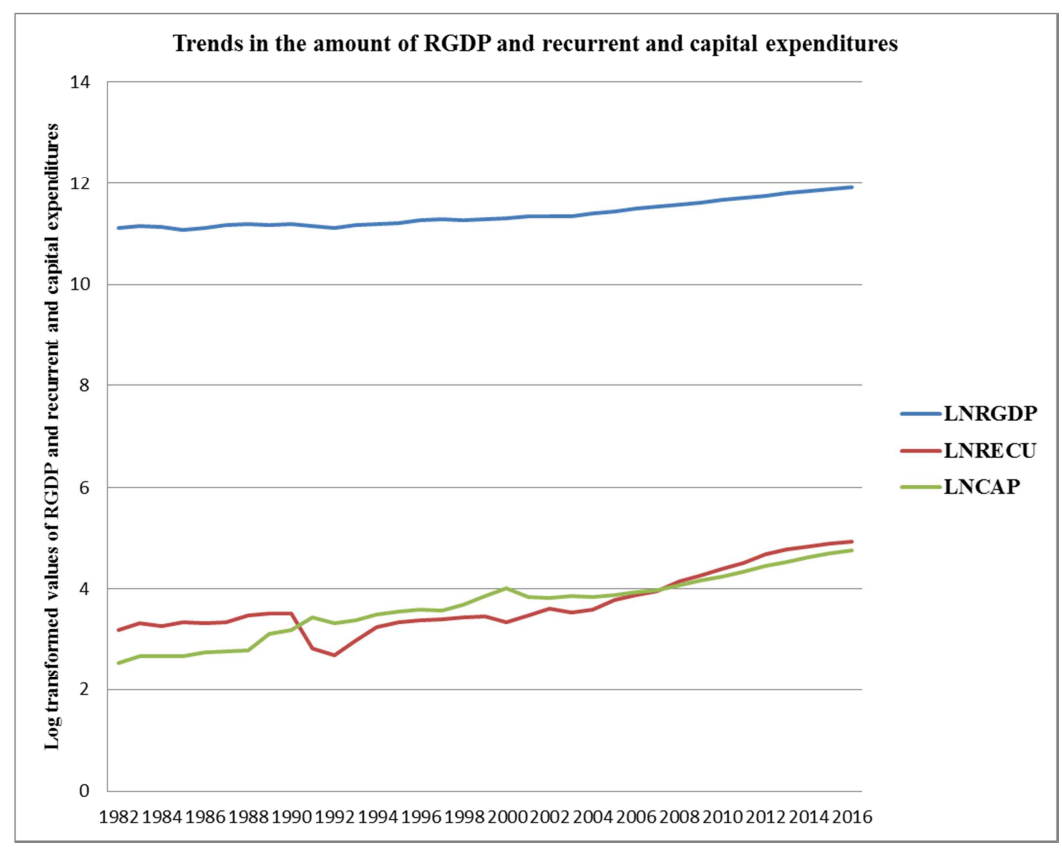

Source: compiled from WDI and EEA data sets.

Figure 3. Trends of Economic growth and Recurrent and Capital Expenditure.

From 1999 to 2000/01, at the time of Ethio-Eritrea war, recurrent expenditure shows decline while capital expenditure was on the opposite direction. In between 1991 and 2007, capital expenditure lies above recurrent expenditure. For those years before 1991 and after 2008, recurrent expenditure exceeds capital expenditure.

\subsection{Econometric Analysis}

\subsubsection{Pre-regression Tests}

Before the estimation of the VAR model, data need to be stationary and integrated of the same order. Therefore, test for stationarity, causality and co-integration tests will be conducted as follows.

\subsubsection{Test for Stationarity}

The study employed the Augmented Dickey Fuller (ADF) to test the order of integration of both the dependent and independent variables. The unit root test results are presented in table 2 below. As it is revealed in the table, the dependent and all independent variables are stationary at their first difference.

Table 2. Unit root test result based on ADF test.

\begin{tabular}{llll}
\hline Variables & ADF test statistics & Critical values & Order of integration \\
\hline & & $1 \%$ level $(-3.750)$ & Stationary at $1^{\text {st }}$ difference \\
LNRGDP & -6.831 & $5 \%$ level $(-3.000)$ & \\
& & $10 \%$ level $(-2.630)$ & Stationary at $1^{\text {st }}$ difference \\
\hline
\end{tabular}




\begin{tabular}{|c|c|c|c|}
\hline Variables & ADF test statistics & Critical values & Order of integration \\
\hline \multirow{5}{*}{ LNEDUC } & & $10 \%$ level $(-2.630)$ & \\
\hline & & $1 \%$ level $(-3.750)$ & \\
\hline & -4.853 & $5 \%$ level $(-3.000)$ & Stationary at $1^{\text {st }}$ difference \\
\hline & & $10 \%$ level $(-2.630)$ & \\
\hline & & $1 \%$ level $(-3.750)$ & \\
\hline \multirow[t]{3}{*}{ LNROAD } & -4.983 & $5 \%$ level $(-3.000)$ & Stationary at $1^{\text {st }}$ difference \\
\hline & & $10 \%$ level $(-2.630)$ & \\
\hline & & $1 \%$ level $(-3.750)$ & \\
\hline \multirow[t]{3}{*}{ LNENER } & -4.951 & $5 \%$ level $(-3.000)$ & Stationary at $1^{\text {st }}$ difference \\
\hline & & $10 \%$ level $(-2.630)$ & \\
\hline & & $1 \%$ level $(-3.750)$ & \\
\hline \multirow[t]{3}{*}{ LNRECU } & -5.028 & $5 \%$ level $(-3.000)$ & Stationary at $1^{\text {st }}$ difference \\
\hline & & $10 \%$ level $(-2.630)$ & \\
\hline & & $1 \%$ level $(-3.750)$ & \\
\hline \multirow[t]{2}{*}{ LNCAP } & -4.578 & $5 \%$ level $(-3.000)$ & Stationary at $1^{\text {st }}$ difference \\
\hline & & $10 \%$ level $(-2.630)$ & \\
\hline
\end{tabular}

Source: compiled from Eviews results.

Note that $5 \%$ significance level is used for the decision of Unit root.

\subsubsection{Granger Causality Test}

Granger causality test is used to examine the relationship between the variables included in and the relevance of using a VAR model. If the variables are endogenously related to each other in the system, the use of a VAR model is valid. The test shows whether any variable granger causes the other variable in the system and/or vice versa. The Grangercausality test from table 3 below shows that, real GDP is not exogenous. Change in real GDP can be caused by at least two variables in the system; namely expenditure on agriculture (LNAGR) and educational expenditure (LNEDUC).

Table 3. Chi-square statistics and respective p-value for Granger Causality Test.

\begin{tabular}{|c|c|c|c|c|c|c|c|c|}
\hline Variables & LNRGDP & LNAGR & LNEDUC & LNROAD & LNENER & LNCAP & LNRECU & All \\
\hline LNRGDP & ----- & $\begin{array}{l}11.9543 \\
(0.0002)\end{array}$ & $\begin{array}{l}6.74327 \\
(0.0041)\end{array}$ & $\begin{array}{l}2.04393 \\
(0.1484)\end{array}$ & $\begin{array}{l}0.01706 \\
(0.9831)\end{array}$ & $\begin{array}{l}0.90000 \\
(0.4180)\end{array}$ & $\begin{array}{l}1.69005 \\
(0.2028)\end{array}$ & $\begin{array}{l}11.18424 \\
(0.5132)\end{array}$ \\
\hline LNAGR & $\begin{array}{l}3.51500 \\
(0.0435)\end{array}$ & ----- & $\begin{array}{l}5.58571 \\
(0.0091)\end{array}$ & $\begin{array}{l}2.27839 \\
(0.1211)\end{array}$ & $\begin{array}{l}0.42113 \\
(0.6604)\end{array}$ & $\begin{array}{l}5.52453 \\
(0.0095)\end{array}$ & $\begin{array}{l}1.35194 \\
(0.2751)\end{array}$ & $\begin{array}{l}3.912076 \\
(0.1414)\end{array}$ \\
\hline LNEDUC & $\begin{array}{l}2.15862 \\
(0.1343)\end{array}$ & $\begin{array}{l}0.05151 \\
(0.9499)\end{array}$ & ----- & $\begin{array}{l}0.63751 \\
(0.5361)\end{array}$ & $\begin{array}{l}1.95651 \\
(0.1602)\end{array}$ & $\begin{array}{l}1.65907 \\
(0.2085)\end{array}$ & $\begin{array}{l}5.10327 \\
(0.0129)\end{array}$ & $\begin{array}{l}5.157274 \\
(0.0759)\end{array}$ \\
\hline LNROAD & $\begin{array}{l}0.02890 \\
(0.9715)\end{array}$ & $\begin{array}{l}0.33703 \\
(0.7167)\end{array}$ & $\begin{array}{l}3.60856 \\
(0.0403)\end{array}$ & ---- & $\begin{array}{l}0.65534 \\
(0.5270)\end{array}$ & $\begin{array}{l}2.62951 \\
(0.0898)\end{array}$ & $\begin{array}{l}3.85416 \\
(0.0332)\end{array}$ & $\begin{array}{l}4.978722 \\
(0.0830)\end{array}$ \\
\hline LNENER & $\begin{array}{l}7.45704 \\
(0.0025)\end{array}$ & $\begin{array}{l}8.53868 \\
(0.0013)\end{array}$ & $\begin{array}{l}6.52346 \\
(0.0047)\end{array}$ & $\begin{array}{l}7.01187 \\
(0.0034)\end{array}$ & ----- & $\begin{array}{l}2.62189 \\
(0.0904)\end{array}$ & $\begin{array}{l}8.39963 \\
(0.0014)\end{array}$ & $\begin{array}{l}0.835540 \\
(0.6585)\end{array}$ \\
\hline LNCAP & $\begin{array}{l}1.49255 \\
(0.2421)\end{array}$ & $\begin{array}{l}0.75797 \\
(0.4780)\end{array}$ & $\begin{array}{l}1.60460 \\
(0.2189)\end{array}$ & $\begin{array}{l}2.31447 \\
(0.1174)\end{array}$ & $\begin{array}{l}2.69225 \\
(0.0852)\end{array}$ & & $\begin{array}{l}4.71740 \\
(0.0172)\end{array}$ & $\begin{array}{l}0.896128 \\
(0.6389)\end{array}$ \\
\hline LNRECU & $\begin{array}{l}6.80911 \\
(0.0039)\end{array}$ & $\begin{array}{l}8.93820 \\
(0.0010)\end{array}$ & $\begin{array}{l}5.87685 \\
(0.0074)\end{array}$ & $\begin{array}{l}3.61437 \\
(0.0401)\end{array}$ & $\begin{array}{l}0.38853 \\
(0.6817)\end{array}$ & $\begin{array}{l}2.39445 \\
(0.1097)\end{array}$ & ----- & $\begin{array}{l}1.181546 \\
(0.5539)\end{array}$ \\
\hline
\end{tabular}

Source: compiled from Eviews results.

\subsubsection{Co-Integration Test}

Table 4. ADF test for stationarity of the residual term.

\begin{tabular}{lllll}
\hline & Test statistic & $\mathbf{1 \%}$ Critical value & $\mathbf{5 \%}$ Critical value & $\mathbf{1 0 \%}$ Critical value \\
\hline$Z(t)$ & -5.674 & -3.750 & -3.000 & -2.630 \\
\hline
\end{tabular}

Source: compiled from Eviews results.

From the above table we can conclude that, as far as the tstatic value is greater than the critical values, we can reject the null hypothesis and the residual term is stationary. Stationarity of residual term in turn leads to the conclusion that there is long-run relationship between variables in this study.

\subsection{Regression Results}

\subsubsection{Long-run Model}

The result of the co-integrated VAR from Eviews [9] with two lag selected by the optimum lag length selection criteria gives us the long run model. 


$$
\text { LNRGDP }=\underset{(0.006)}{0.09 \text { LNAGR }}+\underset{(0.014)}{0.33 \text { LNEDUC }}+\underset{(0.005)}{\text { 0.14LNROAD }}+\underset{(0.003)}{\text { 0.04LNENER }}+\underset{(0.004)}{0.06 \mathrm{LNCAP}}+\underset{(0.005)}{0.12 \mathrm{LNRECU}}+22.22
$$

The numbers in parenthesis under the estimated coefficients are the asymptotic standard errors.

As explained in the long-run equation above, growth of real domestic product (RGDP) in the long run is affected by expenditures on recurrent transactions (RECU), energy including mining (ENER), education (EDUC), capital expenditure (CAP) and expenditure on agriculture (AGR) and road (ROAD). All areas of public expenditure affect economic growth positively but with different magnitude. Expenditure on energy takes the lowest share in explaining economic growth in which its one percent increase will bring only 0.04 percent economic growth followed by capital expenditure which is one percent increase brings 0.06 percent economic growth.

Despite having agriculture based economic development strategy, the power of agricultural expenditure in stimulating economic growth is not much powerful in such that a one percent increase in agricultural expenditure will generate a 0.09 percent increase in real GDP growth rate even it is lower than the growth explanatory power of expenditure on road which is one percent increase leads to a 0.14 percent.

Compared to capital expenditure, recurrent expenditure contributes a lot in economic growth in which a 1 percent increase in recurrent expenditure stimulates a 0.12 percent economic growth. This is due to the nature of economic activities in the country and the higher composition of civil servants out of the total labor force. Most of the economic activities are primary like agriculture and tertiary like the service sector which have more of recurrent nature than capital structure.

In the long-run, education is the most important variable to bring economic growth. As the expenditure in education increase by 1 percent, in the long-run the economy will grow by 0.33 percent. This is by far the highest explanatory power among the given variables.

\subsubsection{Short-run Model}

After identifying the long run relationship among the variables, the estimated vector error correction model explains the short run relationship. Table 5 below summarizes the short run relationship between the dependent variable RGDP and independent variables AGR, EDUC, ENER, ROAD, RECU and CAP using the result of the equation D (RGDP) in the error correction model. The adjusted R-square shows that $59.70 \%$ of the variation in real GDP growth is explained by the combined effects of all the determinants of real GDP in the short-run (table 5).

Table 5. Error Correction Model.

\begin{tabular}{lllll}
\hline & Coefficient & Std. Error & t-Statistic & Prob. \\
\hline ECM1 (-1) & -1.278945 & 0.415514 & -3.077986 & 0.0072 \\
D (LNRGDP (-1)) & 0.250983 & 0.251192 & 0.999169 & 0.3326 \\
D (LNRGDP (-2)) & -0.098068 & 0.211858 & -0.462896 & 0.6497 \\
D (LNROAD (-1)) & 0.009150 & 0.060192 & 0.152020 & 0.8811 \\
D (LNROAD (-2)) & 0.102729 & 0.046054 & 2.230607 & 0.0404 \\
D (LNRECU (-1)) & 0.039050 & 0.046658 & 0.836929 & 0.4150 \\
D (LNRECU (-2)) & -0.046266 & 0.047082 & -0.982676 & 0.3404 \\
D (LNENER (-1)) & -0.019537 & 0.025154 & -0.776701 & 0.4487 \\
D (LNENER (-2)) & 0.002440 & 0.021201 & 0.115101 & 0.9098 \\
D (LNEDUC (-1)) & -0.127913 & 0.188335 & -0.679177 & 0.5067 \\
D (LNEDUC (-2)) & -0.303625 & 0.137973 & -2.200620 & 0.0428 \\
D (LNCAP (-1)) & -0.082476 & 0.089611 & -0.920373 & 0.7275 \\
D (LNCAP (-2)) & -0.021595 & 0.060896 & -0.354618 & 0.4610 \\
D (LNAGR (-1)) & -0.087952 & 0.116447 & -0.755299 & 0.5767 \\
D (LNAGR (-2)) & 0.036558 & 0.064156 & 0.569826 & 0.0482 \\
C & 0.116581 & 0.054500 & 2.139112 & 1.932755 \\
R-squared & 0.792050 & DW stat & 4.062774 & \\
Adjusted R-squared & 0.597097 & F-statistic & & \\
\hline
\end{tabular}

Coefficient of the error correction term, which is the speed of adjustment towards equilibrium, is expected to be negative and significant. Based on this its coefficient is negative (1.27) and significant (because the t-statistic value (3.07) is greater than the Durbin-Watson statistic value (1.93), p-value as well less than $5 \%$ )). Since the coefficient of the error correction term is negative and significant, we can say that there is long-run causality running from independent variables, (AGR, EDUC, ENER, ROAD, RECU and CAP) to dependent variable (RGDP).

As the coefficient of error correction term indicates, RGDP adjusts to its long-run equilibrium by $127 \%$ in one year. This implies that public expenditure components are better significant and positive in the long-run to affect real GDP. From the short-run error correction model above we can explain that, except expenditure on road and education, other variables are insignificant and fail to affect real GDP in the short run. The coefficient for ROAD is significant and positive meaning that expenditure on road has a positive short run effect. Which means, as expenditure on road increase, real GDP will be affected immediately in the same direction. Similarly the coefficient for education is significant but not positive. Having negative coefficient for education implies that, in the short-run the expenditure on education causes real GDP to fall. 


\subsubsection{Diagnostic Tests on the Residual of the Vector Error Correction Model}

Tests of autocorrelation, normality, heteroskedasticity and Exogenity on the residuals of the vector error correction models are conducted with the help of Lagrange-multiplier (LM) test, Jarqu-Bera test, Breusch-Pagan test and RMSE tests respectively. These tests are used to confirm the basic assumptions regarding the residual and the validity of the results in this study. From the tests, it was found that the nulls of no autocorrelation, normality, constant variance and weak Exogenity in the residuals could not be rejected in all cases at $5 \%$ level of significance. Therefore, using the formulated null hypothesis we can conclude that, there is no any problem of misspecification in the model.

\section{Conclusion and Policy Implication}

\subsection{Conclusion}

The result of the study reveals that all the variables are stationary at their first difference meaning that their combinations will not lead to spurious/false regression. The co-integration test also shows that there is long run relationship between these variables (i.e. components of public expenditures and real GDP) and that there is a positive relationship between expenditure on agriculture, education, road, energy, current as well as capital expenditures and real Gross Domestic Product.

The estimation result in the VECM model clearly explains the existence of long run causal relationship which runs from various areas of public expenditure to the growth of real GDP. This means in the long-run all explanatory variables are significant in explaining growth of real GDP. In the short-run only expenditure on road and education has an impact on growth of real GDP.

In some ways these results are not surprising. Using government expenditure as a tool to boost economic growth and enhance the life of the population, Ethiopia has set down both medium and long-term plans. The growth of the economy is essential for sustainable development. Without economic growth, it will be difficult for developing country like Ethiopia to enhance the standard of living for the population.

Therefore, this paper investigated the relationship between Economic growth and various compositions of public expenditures from the co-integrated error correction modeling for the period 1982-2016 G. C. showed that all components of public expenditure has both positive and statistically significant coefficients. This means any increase in public expenditure in either of these variables will have both positive and significant impact on economic growth.

However, the explanatory power of each independent variable has significant differences. From the long-run model, Expenditure on education has the largest contribution to the growth in real GDP, followed by expenditure on road and recurrent expenditure. Expenditure on energy contributes the lowest to the growth of real GDP followed by capital expenditure and expenditure on agriculture.
The short-run relationship in the VECM model summarizes that, except expenditure on education and road, in the short-run there is no any significant contribution made from explanatory variables to the growth of real GDP. In the short run expenditure on education has negative impact on the growth of real GDP whereas; expenditure on road has positive impact.

\subsection{Policy Implications}

This is an area ripe for research that could have important policy implications. Infrastructure must be paid for. According to the conclusion and the result of the model, it is important to have growing public expenditures on various areas so as to stimulate growth in real GDP. But this have to made without forgetting that there is a growth maximizing level of public infrastructural expenditures, which crowd out private participations if it goes beyond that level.

Based on the findings of this study, regarding the impact of public Expenditure components on Economic growth in Ethiopia, the following policy recommendations have to be made;

Since the impact of public expenditure on economic growth is positive and significant in the long-run, the government needs to raise the amount of public expenditure at all. But there must be some considerations on the proportion of expenditure to various sectors based on their level of significance.

Based on this more expenditure should be allocate for education as far as its long-run contribution to the growth of real GDP is very much significant. Education has an indirect long-run significant contribution to economic growth in the form of providing human capital. Much more expansion of education and educational training will enhance labor productivity and raise the entrepreneurial skill of the people, which in turn leads to higher output contribution that cause for economic growth.

Road, one among important economic infrastructures, has both long run and short run positive and significance role in explaining economic growth. Therefore, it is important to raise the level of expenditure on this sector so as to bring significant economic growth.

Regarding recurrent expenditure, the government has better to spend more, with consideration of the problem of inflation, since such expenditures have essential in facilitating liquid transactions which increases current aggregate demand.

Generally, public expenditure is important for economic growth but it needs adjustment to switch these expenditures form nonproductive and lower significant areas to productive and more significant areas.

\section{References}

[1] Abdu M. \& Melesse A., (2014). Government spending for economic growth in Ethiopia, Journal of Economics and Sustainable Development ISSN 2222-1700 (Paper) ISSN 2222-2855 (Online) Vol. 5, No. 9, 2014. 
[2] Alicia H. Munnell, (1992), Infrastructure investment and economic growth, Journal of Economic Perspectives Volume 6, Number 4 - fall 1992 - Pages 189-198.

[3] Baum, W. C., \& Tolbert, S. M. (1985). Investing in development; Lessons of World Bank experience. New York, NY: Oxford University Press.

[4] C. Calderón and L. Servén, (2010) Infrastructure, Growth, and Inequality; An Overview, 2010.

[5] David Alan Aschauer, (1989), is public expenditure productive? Journal of Monetary Economics 23 (1989) 177 200. North-Holland.

[6] David Canning \& Peter Pedroni, (2004) the effects of infrastructure on long run economic growth.

[7] Development Assistant Group Ethiopia (DAG).(2006). DAG response to PASDEP. Retrieved fromhttp://www.dagethiopia.org/index.php?option=com_conte nt\&viewarticle\&id14\&Itemid page; 40.

[8] Easterly, W. (2003). National Policies and Economic Growth: A Reappraisal, Working Paper No. 27, Center for Global Development, New York University.

[9] EViews 3.1 User's Guide (1999), Quantitative Micro Software, LLC, 3rd Edition, USA.

[10] George J. \& J. Bratsiotis, (2005). Influential Price and Wage Setters, Monetary Policy and Real Effects, School of Economics Discussion Paper Series 0540, Economics, the University of Manchester.
[11] Glenn D. Otto \& Graham M. Voss, (1995), is public capital provision efficient? Journal of Monetary Economics 42 (1998) 47-66, School of Economics, University of New South Wales, Sydney 2052, Australia.

[12] Harris S., and Sollis G,. (2003). Optimal taxation, economic growth and income inequality, Public Choice 115: 299-312.

[13] John Njenga M., George K., James M. \& Gideon K. Thuku, (2013) the impact of public expenditure components on economic growth in Kenya 1964-2011, International Journal of Business and Social Science Vol. 4 No. 4.

[14] Mesghena M., (2011). Government Expenditures and Economic Growth in Jordan International Conference on Economics and Finance Research, IPEDR vol. 4.

[15] Ministry of Finance and Economic Development of Ethiopia (MoFED) (2006). Guide lines for the preparation of public sector projects. Addis Ababa, Ethiopia.

[16] Shiferaw, A. T., Klakegg, O. J., \&Haavaldsen, T., (2012). Governance of public investment projects in Ethiopia. Project Management Journal, 43(4), 52-69.

[17] Wahab, M. (2004). Economic growth and government expenditure: evidence from a new test specification, Applied Economics, 36, 2126-2127.

[18] World Bank, (2004), Public Investment and Fiscal Policy; Prepared by the Fiscal Affairs Department and the Policy Development and Review Department, March 12, 2004. 